Received October 30, 1972.

1 Angseesing, J. P. A., Nature, 239, 408 (1972).

${ }^{2}$ Koestler, A., The Case of the Midwife Toad (Hutchinson, London, 1971).

${ }^{3}$ Waddington, C. H., The Strategy of the Genes (Allen and Unwin, London, 1957).

4 Wersky, P. G., Nature, 234, 489 (1971).

\section{Elevated Arterial Blood Pressure in an Asymptotic Population of Meadow Voles (Microtus pennsylvanicus)}

THE factors regulating the growth and final size of mammalian populations include climatic conditions, availability of food, predation, disease, and intraspecific strife $\mathrm{e}^{1-\mathrm{s}}$. In studies of the demography and organ weight changes in increasing animal numbers in freely growing confined populations of mice, Christian, Lloyd and Davis ${ }^{4}$ have observed that the population growth curve will reach an asymptote after which the population remains close to this size. The attainment of the upper asymptote is associated with cessation of rearing of all young animals. It is not known why reproduction fails at high density but it may involve behavioural changes, failure of lactation and increased intrauterine mortality.

There are many data on the growth rates and organ weights of confined populations but little is known about the physiological status of these animals. In this study a population of meadow voles (Microtus pennsylvanicus) was

Table 1 Measurements of Animals from a Freely Growing Confined Population and Caged as Bisexual Pairs

\begin{tabular}{|c|c|c|c|c|c|c|c|}
\hline & & opulation & & & & exual pai & \\
\hline Sex & Age * & $\begin{array}{c}\text { Body } \\
\text { weight }+\end{array}$ & $\begin{array}{c}\text { Blood } \\
\text { pressure }\end{array}$ & Sex & Age* & $\begin{array}{c}\text { Body } \\
\text { weight } \uparrow\end{array}$ & $\begin{array}{c}\text { Blood } \\
\text { pressure }\end{array}$ \\
\hline $\mathbf{M}$ & 374 & 53 & 120 & $\mathbf{M}$ & 482 & 46 & 120 \\
\hline $\mathrm{F}$ & 374 & 50 & 120 & $\mathbf{F}$ & 449 & 40 & 112 \\
\hline $\mathbf{M}$ & 308 & 64 & 122 & $F$ & 378 & 36 & 105 \\
\hline $\mathrm{F}$ & 240 & 43 & 110 & $\mathrm{~F}$ & 377 & 39 & 98 \\
\hline $\mathrm{F}$ & 195 & 68 & 120 & $\mathbf{M}$ & 295 & 64 & 112 \\
\hline$F$ & 195 & 69 & 115 & $\mathbf{F}$ & 293 & 32 & 115 \\
\hline $\mathrm{F}$ & 195 & 62 & 117 & $\mathrm{~F}$ & 278 & 44 & 90 \\
\hline $\mathbf{M}$ & 178 & 71 & 122 & $\mathrm{M}$ & 242 & 46 & 122 \\
\hline $\mathbf{M}$ & 178 & 51 & 117 & $\mathrm{~F}$ & 220 & 37 & 102 \\
\hline $\mathrm{F}$ & 178 & 54 & 125 & $F$ & 196 & 36 & 98 \\
\hline $\mathrm{F}$ & 178 & 42 & 135 & $\mathrm{~F}$ & 196 & 42 & 110 \\
\hline $\mathbf{M}$ & 85 & 55 & 133 & $\hat{F}$ & 161 & 59 & 105 \\
\hline$F$ & 85 & 50 & 120 & $\mathbf{M}$ & 158 & 42 & 112 \\
\hline $\mathrm{M}$ & 85 & 36 & 123 & $\mathrm{M}$ & 140 & 27 & 100 \\
\hline & & & & $\mathrm{F}$ & 118 & 54 & 95 \\
\hline & & & & $\mathrm{M}$ & 116 & 52 & 115 \\
\hline & & & & $\mathrm{F}$ & 116 & 24 & 120 \\
\hline & & & $\bar{x} 121$ & & & & $\vec{x} 107$ \\
\hline
\end{tabular}

* In days. $†$ In g. $\ddagger$ In $\mathrm{mm} \mathrm{Hg}$.

allowed to reach its asymptotic density and arterial blood pressure was measured. Animals caged as bisexual pairs served as controls.

The population was housed in a stainless steel cage divided into two communicating levels each measuring $2 \times 4.5$ foot. Litter material included wood shavings and newspaper placed in the cage at the start of the experiment and not changed, and metal cans were provided as nest sites. Excess food and water were provided, and the light. ing, temperature and humidity were controlled. The population was started by introducing one male and two female weanling voles into the cage and leaving them undisturbed except for a monthly census. The population was allowed to grow until reproduction ceased as indicated by a lack of new animals present after three consecutive months. The voles were anaesthetized with urethane $\left(1 \mathrm{~g} \mathrm{~kg}^{-1}\right)$, a carotid artery cannulated with polyethylene tubing (PE 10) and the mean arterial pressure recorded with a 'Statham' strain gauge and 'Gilson' recorder. If any blood loss occurred or the cannula was not patent, the data were not included in the results. Organ weights were determined after fixation in $10 \%$ neutral buffered formalin. Animals of approximately the same age distribution, caged as breeding pairs, were used as controls for the animals from the freely growing population, and their blood pressure was measured identically.

The population was terminated after 354 day; the last litter from which any animals survived beyond weaning was born at 270 day. At sacrifice there were twenty-two voles present of which twelve were females and ten were males. Of the females, seven were pregnant but four had resorbing embryos.

Measurement of the blood pressure was successful in fourteen of the twenty-two population animals and seventeen of the twenty control animals. The mean blood pressure of the population was $121 \pm 1.7$ (s.e.m.) $\mathrm{mm} \mathrm{Hg}$ while that from the control animals was $107 \pm 2.3$. By Student's $t$ test for group comparisons, this difference is very highly significant with $P<0.001$. The only significant difference between organ weights observed was that the thymus glands of animals from the population were smaller $\left(0.42 \pm 0.05 \mathrm{mg} \mathrm{g}^{-1}\right.$ body wt) when compared to the control animals $(0.90 \pm 0.10)(P<0.001)$.

Bernardis and Skelton ${ }^{5}$ reported that rats with adrenal regeneration hypertension showed greater increases of blood pressure when housed three per cage as compared to singly caged rats. Henry et al. ${ }^{6}$ observed raised blood pressure in crowded mice and these workers, as well as others $^{7,8}$, have pointed out that social pressures or stress may be involved in the genesis of essential hypertension. My study shows that when animals are allowed to interact until they reach a high stable population density they demonstrate a small, but consistent, elevation in blood pressure. There is evidence that cessation of reproduction may be associated with an altered state of the pituitaryadrenal-gonadal system ${ }^{4}$, and many investigators have also demonstrated a relationship between adrenal steroids and hypertension ${ }^{9}$.

Because thymic involution is a recognized indication of increased adrenocortical function, I suggest that the occurrence of hypertension in asymptotic populations might also be a function of increased adrenocortical function.

I thank Drs J. J. Christian and J. A. Lloyd for valuable discussions. This work was supported by a grant from the US National Institute of Mental Health.

\section{E. H. Blaine}

Howard Florey Institute of Experimental

Physiology and Medicine,

University of Melbourne,

Parkville, Victoria 3052

Received October 5; revised November 27, 1972.

${ }^{1}$ Christian, J. J., and Davis, D. E., Science, 146, 1550 (1964).

2 Myers, K., and Poole, W. E., CSIRO Widl. Res., 8, 166 (1963).

${ }^{3}$ Chitty, D., Can.J. Zool., 38, 99 (1960).

${ }^{4}$ Christian, J. J., Lloyd, J. A., and Davis, D. E., Rec. Prog. Hormone Res., 21, 501 (1965).

5 Bernardis, L. L., and Skelton, F. R., Proc. Soc. Exptl. Biol. Med., 113, 952 (1963).

${ }^{6}$ Henry, J. P., Meehan, J., and Stephans, P. M., Psychosom. Med., 29, 408 (1967).

${ }^{7}$ Scotch, N. A., and Geiger, H. J., J. Chron. Dis., 1183 (1963).

8 Henry, J. P., and Cassel, J. C., Amer. J. Epidem., 90, 171 (1969).

9 Cope, C. L., Adrenal Steroids and Disease, 516 (Pitman, London, 1964). 